International Journal of Social Sciences and Humanities
Available online at http://sciencescholar.us/journal/index.php/ijssh
Vol. 1 No. 3, December 2017, pages: 194 204
e-ISSN: 2550-7001, p-ISSN: 2550-701X
https://doi.org/10.29332/ijssh.v1n3.312

\title{
Syntactic Frames and Deep Structure Specification of Semantic Prime 'Do' in Balinese
}

\begin{abstract}
$\underset{\text { CrossMark }}{\text { \&licktor updrases }}$
I Made Netra ${ }^{a}$

Article history: Received 09 August 2017, Accepted in revised form 18 December 2017, Approved 27 December 2017, Available online 31 December 2017

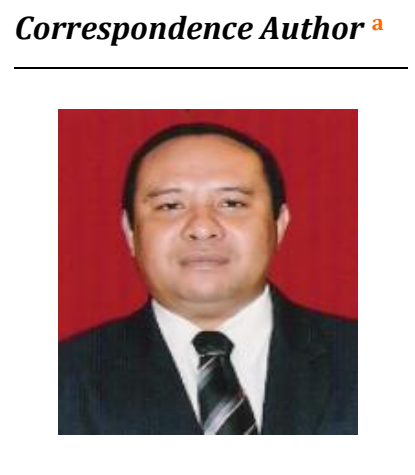

\section{Keywords}

case role;

control verb;

deep structure;

semantic prime;

syntactic frame;

Abstract

The deep structure specification consists of a control verb and a series of case roles which are marked in the Noun Phrase (NP). Study about the deep structure specification for the semantic prime DO is related to the case grammar of which model is determined by the syntactic frames of the semantic prime DO. Therefore, this article tries to describe the syntactic frames and the case roles of the semantic prime DO. Data were collected from four Balinese folklores with observation method and note taking technique. The Descriptive qualitative method was used to analyze the data collected. The results of the analysis showed that the syntactic frames of the semantic prime DO can be described as (1) $\mathrm{X}$ does (something) in which the deep structure can be specified into A-O and B/E-O where B is coreferential with E; (2) X does (something) to/for/with someone / something in which the deep structure can be specified into $\mathrm{O}-\mathrm{A}$ where $\mathrm{S}=\mathrm{O}, \mathrm{A}-\mathrm{O}-\mathrm{B}, \mathrm{B}-\mathrm{Os}$, and $\mathrm{A}-\mathrm{O}$; (3) $\mathrm{X}$ does (something) in something in which the deep structure can be specified into Os-L, A-O-L, and $\mathrm{E}$-L; and (4) X does (something) to/for/with someone/something in something in which the deep structure can be specified into O-A-L and B/E-L where B is coreferential with E.
\end{abstract}

e-ISSN: 2550-7001, p-ISSN: 2550-701X ${ }^{\odot}$ Copyright 2017. The Author. SS Journals Published by Universidad Técnica de Manabí. This is an open-access article under the CC BY-SA 4.0 license (https://creativecommons.org/licenses/by-sa/4.0/) All rights reserved.

\section{Contents}

Abstract 194

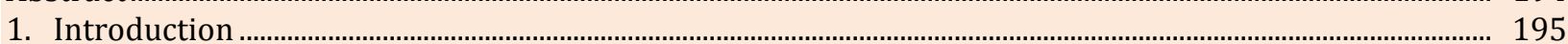

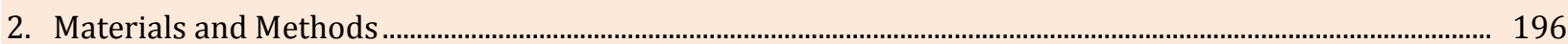

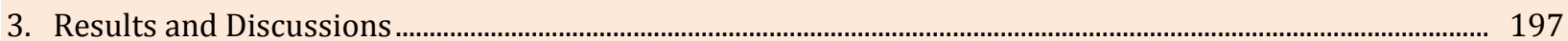

3.1 Syntactic Frames for Semantic Prime DO in Balinese ......................................................................................... 197

3.2 Deep Structure Specification Of Semantic Prime Do In Balinese .................................................................. 199

4. Conclusion.................................................................................................................................................................. 203

a Udayana University, Denpasar, Indonesia 


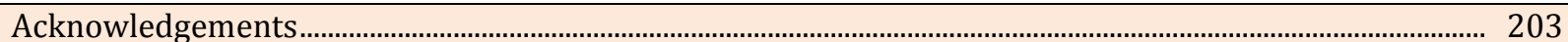

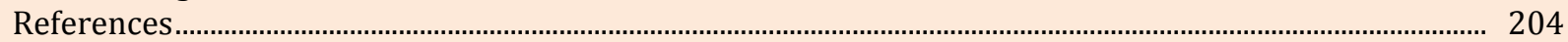

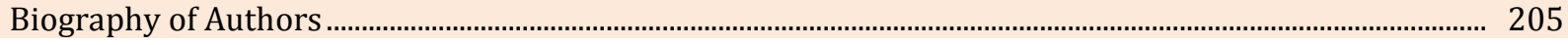

\section{Introduction}

Balinese language is one of the national languages in the country that has a function as a symbol of pride and identity of the people of Bali. Until now it is still maintained by its speakers, as it describes the relation of local wisdom values. Many social activities in the community have been made in Balinese language as media of communication. In addition, folklore has been written in Balinese language (Netra, 2010; 2011; 2012; 2013; 2014; 2009).

The language used in folklore is considered to contain such rules of grammar as Syntax and Semantics. Syntactically language is built based on the structure of sentences and their syntactic frames. While from the semantic point of view, the constructed sentence should be meaningful. Therefore, the sentence has a surface structure and deep structure. The meaning of structures can be seen from the deep structure, specifically from the semantic roles of the entity that builds the sentence. Entities in the sentence can usually be filled with Noun Phrase. Thus the syntax and Semantics are associated with each other.

The relation between form and function is an example of communicative patterning in a different dimension in order to know how the structure of the sentence is related to the meaning of the sentence. Semantic structure is a very significant component of language. Lack of understanding of the structure of natural language semantics leads to failure in describing the language itself. Therefore, the semantic structure is the formation of semantic lexicon features that will present arguments in the semantic structure. The semantic structure is relational semantic network in the lexical system of a language. Semantic structures of semantic components determine the outer structure of the language. Without knowledge of the semantic structure, an explanation of the process of the formation of a good speech cannot be definitely made.

Wierzbicka (1996), said that the main assumption underlying the natural semantic metalanguage (NSM) is that a form of a language or sign cannot be analyzed into a form that is not the form itself. In other words, it can be said that the analysis of meaning would not be possible with a combination of the meaning of other forms. Therefore, the meaning of a lexicon is the configuration of a set of meaning. One offered natural semantic prime DO. Semantic prime DO in Balinese language can be realized in a variety of forms of verbs. These verbs are able to bind the entity that precede and follow it. These verbs have the syntactic frames of that have semantic roles or deep structure specification.

\section{Semantic Prime DO in Balinese}

Wierzbicka (1996), initiated a study produced several prototypes of semantic primes which are represented by several derivatives words. According to her, the NSM theory is used to analyze the semantic primes and their semantic structures. This theory is also developed for analyzing the philosophical meaning that combines both the tradition and logic. The semantic prime of which belong to the prototype of action is DO. The semantic prime DO can be represented by some action verbs, process verbs, and state verbs. If types of verbs are used to build a sentence, it would require several units that can be placed before the verb and after the verb. These units can form a word or phrase. Semantically, words or phrases that are placed before and after the verb are the so-called arguments or entities.

Semantic roles of arguments of the control verb can be analyzed. It is important to know participants involved in that language. Thus, the relationship between predicator and arguments can be understood in a particular proposition. This is done for the purpose of explication of semantic primes. The meaning of lexicon in the configuration of semantic prime and it is not determined by the meaning of another lexicon. The semantic prime is not a new concept in the semantic of which existence has been recognized in the $17^{\text {th }}$ century by the experts (Goddard, 1994; Wierzbicka, 1996d).

The semantic prime is one of the important theoretical concepts in the NSM theory. It is a limited set of meanings that does not change. In this sense, there are also semantic features that will not change (Goddard,

Netra, I. M. (2017). Syntactic frames and deep structure specification of semantic prime 'do' in Balinese. International Journal of Social Sciences and Humanities, 1(3), 194-204. https://doi.org/10.29332/ijssh.v1n3.312 
1996a). The semantic prime is a reflection of the formation of the human mind that is inherited by humans since birth.

To represent it, the semantic prime can be explicated by paraphrasing using natural languages and the words intuitively related to or have the same semantic field, and do not use language that is technical (Wierzbicka, 1996d). Thus, the existence of the semantic prime of the concept is theoretically believed to have an impact. It can be used to explain the overall of complex meaning in much simpler ways. Regularity in the semantic prime is the cause. It means that, if the entire lexicon is comprehensively analyzed, the regular feature can be found. The more semantic prime and regularity can be described, the more the changes and developments of meaning can be determined.

The need for a universally based metalanguage in human science has been well illustrated by the recent interdisciplinary debates on the nature of human emotions (Wierzbicka, 1996). Goddard stated in his semantic principle that the semantic primitives and their elementary syntax exist as a minimal subset of ordinary natural language. The distinctive idea behind the NSM theory is that the irreducible semantic core of any language exists as a subset of the language.

Prototype of action of semantic prime DO can be represented by some of the words in Balinese. Those words are mapped by types of the verb, such as action verbs and process verbs, and state verb, as follows:

Action Verbs:

1) Paum 'to meet'

2) Nayanang 'to deceive'

3) Masang 'to place'

4) Sengit 'to get angry'

5) Nomplok 'to hit'

6) Maumah 'to live'

7) Ngoyong 'to take arest'

8) Meli 'to buy'

9) Mapengarah 'to inform'

10) Nyemak ' to take'

11) Mulih 'to return home'

12) Ngaba 'to bring'

13) Ngamah 'to eat'

14) Negakin 'to get on'

15) Ngalih 'to look for'

16) Makeber 'to fly'

17) Macelep 'to enter'

18) matiang 'to kill'

19) tanem 'to burry'

Process Verbs

1) Nyemuh 'to dry out'

2) Mataluh 'to lay eggs'

3) Ngliling 'to roll'

4) Ngelebengang 'to cook'

State Verb

Maan 'to obtain'

\section{Materials and Methods}

The data were collected from collection of Balinese folklores in Satua Satua Bali X. There are four stories in the story book part X. They are Satua Pan Balang Tamak, Satua Nang Bangsing Teken I Belog, Satua Taluh Mas, and Satua I Bawang Teken I Kesua... Data were collected and classified in accordance with the syntactic frames of semntic prime DO in Balinese. There are four syntactic frames where data could be collected. All the 
data were classified into 1) $\mathrm{X}$ does (something); 2) X does (something) to/for/with someone/something; 3) X does (something) in something; 4) $\mathrm{X}$ does (something) to/for/with someone/something in something. The method used to collect the data was observation method with note taking technique. Furthermore, some steps were taken to obtain valid data, as follows:

1) Identifying and mapping the syntactic frames of semantic primes Do

2) Reading the four stories in Balinese folklores

3) Underlining every single clause or sentence containing such syntactic frames

4) Taking note all clauses or sentences containing such syntactic frames

5) Classifying them into syntactic frames

6) Coding every data

7) Doing the gloss or free translation of the clause or sentence

After the data were obtained and classified, the next step is to analyze systematically based on the sequence of problems formulated. The method used to analyze the data was descriptive qualitative method using relevant theories (Sudaryanto, 1993). The analysis of data can be described as follows.

1) Describing the syntactic frames of semantic prime Do in Balinese

2) Analyzing the deep structure specification that is relevant to case role study

\section{Results and Discussions}

\subsection{Syntactic Frames for Semantic Prime DO in Balinese}

A semantic prime can be expressed by various forms in different context, a phenomenon known within NSM theory as allolexy. For example: English words person and thing can be regarded as allolexes of SOMEONE and SOMETHING when these primes are combined with determiners and quantifiers. The main research tool in the current search to discover a universal semantic syntax is the notion of the canonical context. In this case, a sentence constituent is composed predominantly of semantic primitives that are hypothesized to be expressible in any language.

Wierzbicka (1996b), says that despite the grammatical patterns of language are specifics, it can always be found universal patterns. These universally grammatical patterns are expressed as sets of basic sentence in various languages. These basic sentence elements are built by the universal lexicon. Relation to universal lexicon elements based on grammar of a language is called natural semantic metalanguage (NSM) syntax. Furthermore, the expert has formulated the principles of the NSM syntax, as follows:

1. Any predictable patterns exist in the languages of the world;

2. The patterns are innate grammar of human cognition; and

3. The universal semantic are used. Therefore with this NSM syntax, semantic structure of an utterance can be predicted

The basic unit of NSM syntax is analogous to the clause, namely, a combination of a substantives (I, YOU, SOMEONE, PEOPLE, SOMETHING) with any one of a range of predicates and some additional elements determined by the nature of the predicate. The elements which may function as predicate are action, events, movement: do, happen, move. The syntax of semantic primes is canonical sentence which deals with valence structure. Valence structure is combination of some prototypes of semantic prime, such as:

1) Argument $1+$ predicate

2) Argument $1+$ predicate + Argument 2

Thus, in terms of syntactic frames, the following patterns are taken into account:

1) Subject (S) + Predicate (P)

2) Subject (S) + Predicate (P) + Complement (C)/Adjunct (A)

3) Subject $(\mathrm{S})+$ Predicate $(\mathrm{P})+$ Object $(\mathrm{O})$

4) Subject (S) + Predicate (P) + Object (O) + Complement (C)/Adjunct (A)

Netra, I. M. (2017). Syntactic frames and deep structure specification of semantic prime 'do' in Balinese. International Journal of Social Sciences and Humanities, 1(3), 194-204. https://doi.org/10.29332/ijssh.v1n3.312 
In terms of valence structure or option, the predicate has valence options. It may combine with one substantive as in "this is good for you" (which may be called Subject Complement). The predicate like DO may even open three slots for substantives. The first opens for slot Subject (S), the second opens for slot Complement (C) and the third opens for slot Object (O)

In English the syntactic frames of the semantic prime DO can be said to open four slots. It has valence options, as follows:

1) $X$ does (something)

2) $X$ does (something) to/for/with someone/something

3) $\mathrm{X}$ does (something) in/at/on something

4) $\mathrm{X}$ does (something) to/for/with someone/something in/at/on something

Based on the list of Balinese action verbs and process verbs which are considered the representation of semantic primes mentioned above, the syntactic frames of Balinese lexicons can be made, as follows:

1) $X$ doses (something), as in

(1-1) Kramane paum nayanang Pan Balang Tamak

VillagerN-3PL-ART meet cheat N-3SG

The villagers held a meeting to deceive Pan Balang Tamak

(1-2) I Belog masang bubu

N-3SG put trap

I Belog put the fish trap

(1-3) Darane mataluh mas

PigeonN-3SG-ART produce eggs gold

The pigeon produced golden eggs

(1-4) I Kesuna nyemuh padi

$\mathrm{N}-3 \mathrm{SG}$ dry rice

I Kesuna dried rice

2) X does (something) to/for/with someone/something

(2-1) Pan Balang Tamak sengitange teken krama desane

$\mathrm{N}-3 \mathrm{SG}$ silence-PASS PREP villagerN-PL-ART

Pan Balang Tamak was silenced by the villagers

(2-2) Nang Bangsing nyemak pipis ajak kurenanne

N-3SG take money PREP wife-POSS

Nang Bangsing took money with his wife

(2-3) Daane dana ento maan pamales emas uli darane ento

Unmarried womanN-SG-ART good ART can get gold PREP N-3SG-ART

The kind unmarried woman could have gold from the pigeon

(2-4) I Kesuna nagih nomplok I Bawang aji blida

N-3SG want N-3SG PREP

I Kesuna wanted to hit I Bawang with Blida

3) $\mathrm{X}$ does (something) in/at/on something

(3-1) Pan Balang Tamak maumah di desa anu

$\mathrm{N}-3 \mathrm{SG}$ live PREP village anu 
Pan Balang Tamak Lived in Anu village

(3-2) I Belog meli ketan di pekene

N-3SG buy sticky rice PREP market-ART

I Belog bought sticky rice at the market

(3-3) Daa Tua dadua ngoyong di Banjar

Unmarried womanN-3SG two live PREP banjar

The two unmarried women lived in Banjar

(3-4) I Kesuna nglilingang iba di oot pesake

$\mathrm{N}-3 \mathrm{SG}$ roll self PREP ore rice-ART

I Kesuna rolled over on the rice ore

4) X does (something) to/for/with someone/something in/at/on something

(4-1) Pan Balang Tamak karahan sangkep olih kramane di banjar

N-3SG PASS-inform meet PREP villager-ART PREP banjar

Pan Balang Tamak was asked to attend meeting by the villagers in banjar

(4-2) Kurenan Nang Bangsinge nglebengang daaran baanga babajanranne di jumahne Wife N-3SG-POSS cook meal give-PASS villager-ART PREP home-ART

Nang Bangsing's wife cooked meals for villagers at home

\subsection{Deep Structure Specification Of Semantic Prime Do In Balinese}

In case grammar models, the deep structure consists of a control verb and a series of case-marked Noun Phrase (NP). The deep structure specification of lexical entry requires a description of the underlying structure. The underlying deep structure may be described in terms of simple predicate, e.g. be, come about, cause. These can be described by the following configuration

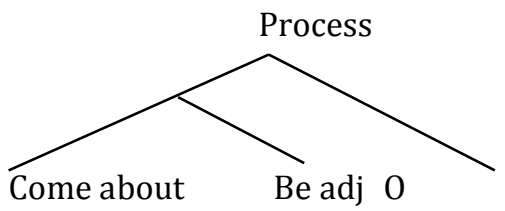

This configuration suggests that the process verb is derived from state by the inchoactive derivation (come about)

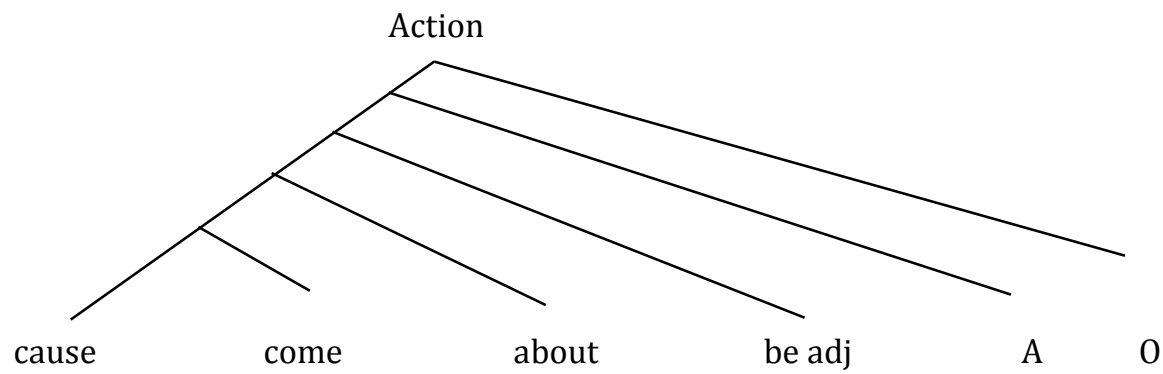

This configuration suggests that the action verb is derived from process by the causative derivation

Netra, I. M. (2017). Syntactic frames and deep structure specification of semantic prime 'do' in Balinese. International Journal of Social Sciences and Humanities, 1(3), 194-204. https://doi.org/10.29332/ijssh.v1n3.312 
The deep structure realized as a verb and a series of cases, the cases defined in a new list, and the case frames for verbs determined this deep structure must then be programmed into surface structure by a series of realization rules. The rules include subject choice, object choice and deletion rules. Cook (1979), presents that the case frame is arranged in a twelve cell matrix of verb types

Table 1

Twelve Cell Matrix of Verb Types

\begin{tabular}{llllll}
\hline No & Verb types & Object & Experience & Benefactive & Locative \\
\hline 1 & States & Os & E - Os & B - Os & Os - L \\
& & (be) tall & (know) & (have) & (be) at \\
2 & Process & O & E - O & B - O & O - L \\
& & (die) & (amuse) & (acquire) & (move) \\
3 & Action & A -0 & A - E - O & A - B - O & A - O - L \\
& & (kill) & (say) & (give) & (bring) \\
\hline
\end{tabular}

Cook (1979), presents 5 propositional cases, as follows:

1) Agent (A) is the case required by an action verb. It is defined as the typically animate doer of the action

2) Experincer (E) is the case required by an experiential verb, such as sensation, emotion, cognition or communication

3) Benefactive (B) is the case required by a benefactive verb.

4) Object $(\mathrm{O})$ is an obligatory case found with every verb

5) Locative (L) is the case required by a locative verb and is restricted to physical location. It is a place of a state, process, or action.

The semantic prime DO has so many representations in Balinese language. Their syntactic frames are categorized into three. They open for slots filled with case marked Noun Phrase (NP). The case roles of the NP preceding and following the semantic prime DO (which may be called a verb) are dependent on the meaning of the verb which may control and instigate the NP. The verb can be in the forms of both action and process verbs. The case roles can be described as follows:

1) X does (something)

(1-1) Kramane paum nayanang Pan Balang Tamak

VillagerN-3PL-ART meet cheat N-3SG

The villagers held a meeting to deceive Pan Balang Tamak
I Belog masang bubu
$\mathrm{N}-3 \mathrm{SG}$ put trap
I Belog put the fish trap

Data (1-1) and (1-2) are all high in valence. They contain action verbs. They are nayanang (deceived) and masang (put) in which they require two Arguments. The verbs control and instigate the first and the second Arguments. In this case, the action verbs require the doer and object. Therefore, the case role of the subject Kramane (the villagers) and I Belog are the Agent (A) and Pan Balang Tamak and bubu (fish trap) are Object (O). Therefore the deep structure of the data can be specified into A-O

(1-3) Darane mataluh mas

PigeonN-3SG-ART produce eggs gold

The pigeon produced golden eggs

(1-4) I Kesuna nyemuh padi

$\mathrm{N}-3 \mathrm{SG}$ dry rice 
I Kesuna dried rice

Data (1-3) and (1-4) are also high in valence but the verb belongs to a process verb mataluh (produced eggs) and nyemuh (dried). The process verb requires two Arguments but the case roles are different. The process verb mataluh (produced eggs) in (1-3) may mean that someone or something that produced eggs is the Befactive in which it experiences something from the process. Meanwhile, the eggs produced may mean something that can be given to the doer. The verb nyemuh (dried) in data (1-4) may mean that the doer did a process so that it can get a kind of experience. Therefore, the case roles of the Arguments darane (the pigeon) and I Kesuna are Benefactive or Experiencer (E) and the second Arguments mas (golden eggs) and padi (rice) are Object (0). Therefore the deep structure can be specified into B/E-O, where B is corefrential with $\mathrm{E}$

2) $\mathrm{X}$ does (something) to/for/with someone/something

Pan Balang Tamak sengitange teken krama desane

$\mathrm{N}-3 \mathrm{SG} \quad$ silence-PASS PREP villagerN-PL-ART

Pan Balang Tamak was silenced by the villagers

Data (2-1) is in passive voice indicated by the verb sengitanga (was silenced). It is high in valence since there are two arguments required by the verb. They are Pan Balang Tamak as Argument 1 and kramane (the villagers) as Argument 2. The case roles of the Arguments are Pan Balng Tamak is Object (O) and Kramane (the villagers) is Agent (A). It can be said that the deep structure can be specified into 0 - $A$ where $S=0$.
Nang Bangsing nyemak pipis ajak kurenanne
$\mathrm{N}-3 \mathrm{SG}$ take money PREP wife-POSS
Nang Bangsing took money with his wife

Data (2-2) is in active voice of which valence is very high since there are more than two arguments required by the verb. The verb nyemak (took) requires more than two arguments in which the verbs control and instigate the Arguments. The case roles of the Arguments are Nang Bangsing is Agent (A), pipis (money) is Object (O) and kurenanne (his wife) is Benefactive (B). The deep structure of data (2-2) can be specified into A-O-B.

\author{
Daane dana ento maan pamales emas uli darane ento \\ Unmarried womanN-SG-ART good ART can get gold PREP N-3SG-ART \\ The kind unmarried woman could have gold from the pigeon
}

Data (2-3) is in active voice of which valence is very high since there are more than two arguments required by the verb. Data (2-3) contains the state verb maan (obtained) and there are two Arguments in the sentence. The first Argument is daane (the unmarried woman), the second Argument is mas (golden eggs). The verb maan (to obtain) belongs to the state verb. All of the Arguments are not controlled and instigated by the verb maan (to obtain) meaning that someone can obtain something from something. Therefore, the case roles of the Arguments are daane (the unmarried woman) is Benefactive (B). Mas (the golden egg) is Object state (Os). The deep structure of the data can be specified into B-Os.

\title{
(2-4) I Kesuna nagih nomplok I Bawang aji blida
}

N-3SG want N-3SG PREP

I Kesuna wanted to hit I Bawang with Blida

Data (2-4) is in active voice of which valence is very high since there are more than two arguments required by the verb. Data (2-4) contains an action verb nomplok (hit) that controls and instigates the Arguments I Kesuna and I Bawang meaning that I Kesuna did something to I Bawang. Therefore, the case role of I Kesuna is Agent (A) and I Bawang is Object (O). The deep structure of the data can be specified into A-O

3) X does (something) in/at/on something

Netra, I. M. (2017). Syntactic frames and deep structure specification of semantic prime 'do' in Balinese. International Journal of Social Sciences and Humanities, 1(3), 194-204. https://doi.org/10.29332/ijssh.v1n3.312 
Pan Balang Tamak maumah di desa anu

N-3SG live PREP village anu

Pan Balang Tamak lived in Anu village

Data (3-1) contain one argument, Pan Balang Tamak. Therefore this is low in valence. The verb maumah (lived) does not control and instigate the argument. Therefore, it is like a state verb. After the verb there is phrase indicating place. The case roles of the clause can be described as Argument Pan Balang Tamak is the Object State (Os) and di desa anu is Locative (L). The deep structure can be specified into Os-L

\section{Belog meli ketan di pekene \\ N-3SG buy sticky rice PREP market-ART \\ I Belog bought sticky rice at the market}

Data (3-2) contains one argument, I Belog. Therefore, it is low in valence. The verb meli (bought) belongs to action verb meaning that it can control the argument preceded. After the verb there is an object ketan (sticky rice) and a phrase indicating a place where the activity of buying takes place. Therefore, the case roles can be described as I Belog is Agent (A), ketan (sticky rice) is Object (O), and di peken is Locatice (L). Therefore, the deep structure of the data can be specified into A-O-L
Daa Tua dadua ngoyong di Banjar
Unmarried womanN-3SG two live PREP banjar
The two unmarried women lived in Banjar

Like data (3-1), data (3-3) contains state verb ngoyong (lived). The verb does not control the Argument preceded. Since there is only one argument in this data, it is then considered low valence. After the verb there a phrase indicating a place where the argument lived. Therefore, the case roles of the argument is Object State $(\mathrm{Os})$ and di Banjar is Locative (L). The deep structure specification is Os - L

$$
\begin{aligned}
& \text { I Kesuna nglilingang iba di oot pesake } \\
& \text { N-3SG roll self PREP ore rice-ART } \\
& \text { I Kesuna rolled over on the rice ore }
\end{aligned}
$$

Data (3-4) contains a process verb nglilingang (rolled over). It does not control the argument. Since there is only one reflective argument then it is low in valence. After the verb there is a place indicating the place where the argument does a process verb. Therefore, the case role of the argument I Kesuna is Experiencer (E) and di oot pesake is Locative. The deep structure can be specified into E-L

4) $\mathrm{X}$ does (something) to/for/with someone/something in/at/on something

$$
\begin{aligned}
& \text { Pan Balang Tamak karahan sangkep olih kramane di banjar } \\
& \text { N-3SG PASS-inform meet PREP villager-ART PREP banjar } \\
& \text { Pan Balang Tamak was asked to attend meeting by the villagers in banjar }
\end{aligned}
$$

Data (4-1) contains the action verb karahin (was asked) which is in passive voice meaning that there must be someone who did it that is asking, and there must be someone who is asked to do something in certain place. This means that the deep structure can be specified into someone who is asking is the doer, the one who is asked is the object and in certain place is location. Therefore, the case roles is Pan Balang Tamak is an Object (0) in which S=0; and di banjar is Locative (L). The doer in this case is kramanne (the villagers) which is specified as Agent (A). Therefore the deep structure of this clause can be specified into O-A-L

(4-2) Kurenan Nang Bangsinge nglebengang daaran baanga babajanranne di jumahne Wife N-3SG-POSS cook meal give-PASS villager-ART PREP home-ART Nang Bangsing's wife cooked meals for villagers at home 
Data (4-2) contains process verb nglebengin (cooked). It shows that there must be someone who is doing something for someone else in certain place. Someone who is doing refers to Kurenan Nang Bangsing (Nang Bangsing's wife). Something which is being processed is daaran (meals). For someone is indicated by baange babanjaranne (for villagers). The place where something is being processed is di jumahne (at home). Kurenan Nang Bangsinge is Agent (A), daaran is Object (0), babajanranne (the villagers) is B/E; di jumahne is Locative (L). Therefore, the deep structure can be specified into A-O-B/E-L, where B is coreferential with E.

\section{Conclusion}

From the above description, some conclusions related to the problems formulated in this paper can be made, as follows:

1) Syntactic frames of semantic prime DO can be described as X does (something), $X$ does (something) to/for/with someone/something, $\mathrm{X}$ does (something) in something, $\mathrm{X}$ does (something) to/for/with/someone/something in something

2) Sentence constructed by the semantic prime DO can be represented by some Balinese verbs which are mapped into action, process, and state verbs. These verbs are able to control and instigate the arguments preceding and following them. So, deep structure specification or a case role of the argument can be described by the propositions of Agent (A), Experiencer (E), Benefactive (B), Object (O), Locative (L).

\section{Acknowledgements}

The author would like thank to the editor of IJSSH dor their valuable time, support, and advice in completing the current research.

Netra, I. M. (2017). Syntactic frames and deep structure specification of semantic prime 'do' in Balinese. International Journal of Social Sciences and Humanities, 1(3), 194-204. https://doi.org/10.29332/ijssh.v1n3.312 


\section{References}

Cook, M. (1979). Perceiving others: the psychology of interpersonal perception (Vol. 675). Taylor \& Francis.

Goddarad, C. (2003). Directive Speech Acts in Malay: Ethnopragmatic Perspective. Christine B. Les Cahiers de Praxematique (Special issue'Langue, discours, cuhure'), 2002b (38), 113-143.

Goddard, C. (1994). Semantic theory and semantic universals. Semantic and lexical universals, 7-29.

Goddard, C., \& Wierzbicka, A. (Eds.). (1994). Semantic and lexical universals: Theory and empirical findings (Vol. 25). John Benjamins Publishing.

Goddard, L., Dritschel, B., \& Burton, A. (1996). Role of autobiographical memory in social problem solving and depression. Journal of Abnormal Psychology, 105(4), 609.

Jerzykiewics, T. (1996). Late Cretaceous dinosaurian habitats of western Canada and central Asia-a comparison from a geological standpoint. Memoirs-Geological Society Of India, 63-84.

Moleong, L. J., \& Kualitatif, M. P. (1994). Bandung. PT Remaja Rosda karya.

Netra, I M. (2012). Tindak Ilokusi Asertif Wacana Slamet Olor Komunitas Petani Adat Bayan, Lombok Utara" dalam Prosiding Seminar Nasional Bahasa Ibu. Denpasar: Prodi S2 Linguistik Program Pascasarjana Universitas Udayana

Netra, I. M. (2010). Kebermaknaan Wacana Ritual Slamet Olor Komunitas Petani Adat Bayan, Lombok Utara." Dalam Prosiding Seminar Internasional Austronesia. Denpasar: Program Studi Linguistik Program Pascasarjana Universitas Udayana

Netra, I. M. (2009). Explication of Utterance Meaning of Ritual Ngusabha at Bulian Village, Kubutambahan Sub District, Buleleng Regency. Prosiding Konferensi Internasional SSEASR. Denpasar ISI dan UNHI

Netra, I. M. (2011). Kajian Semantik Wacana Ritual Nandur Pantun Komunitas Petani Adat Bulian, Kubutambahan, Buleleng, Prosiding Seminar Internasional Bahasa Ibu. Bandung: UPI

Netra, I. M. (2013). Daya ilokusi ngidih 'permintaan'perspektif wacana kebudayaan bali. Linguistika Kultura, 6(3).

Netra, I. M. (2014). Explication and Configuration of Balinese Cultural Script Meanings" dalam Prosiding Kongres Internasional Masyarakat Linguistik Indonesia. Bandar Lampung: Universitas Lampung bekerja sama dengan MLI.

Netra, I. M. (2014). Wacana Budaya dalam Bahasa Bali" dalam Buku Cahaya Bahasa, Persembahan Tulus kepada I Gusti Made Sutjaja. Denpasar: Swasta Nulus.

Sudaryanto. (1993). Metode dan aneka teknik analisis bahasa: pengantar penelitian wahana kebudayaan secara linguistis. Duta Wacana University Press.

Wierzbicka, A. (1996). Contrastive sociolinguistics and the theory of" cultural scripts": Chinese vs English. Contributions to the sociology of language, 71, 313-344.

Wierzbicka, A. (1996). Japanese cultural scripts: Cultural psychology and" cultural grammar". Ethos, 24(3), 527-555.

Wierzbicka, A. (1996). Semantics: Primes and universals: Primes and universals. Oxford University Press, UK.

\section{Biography of Author}

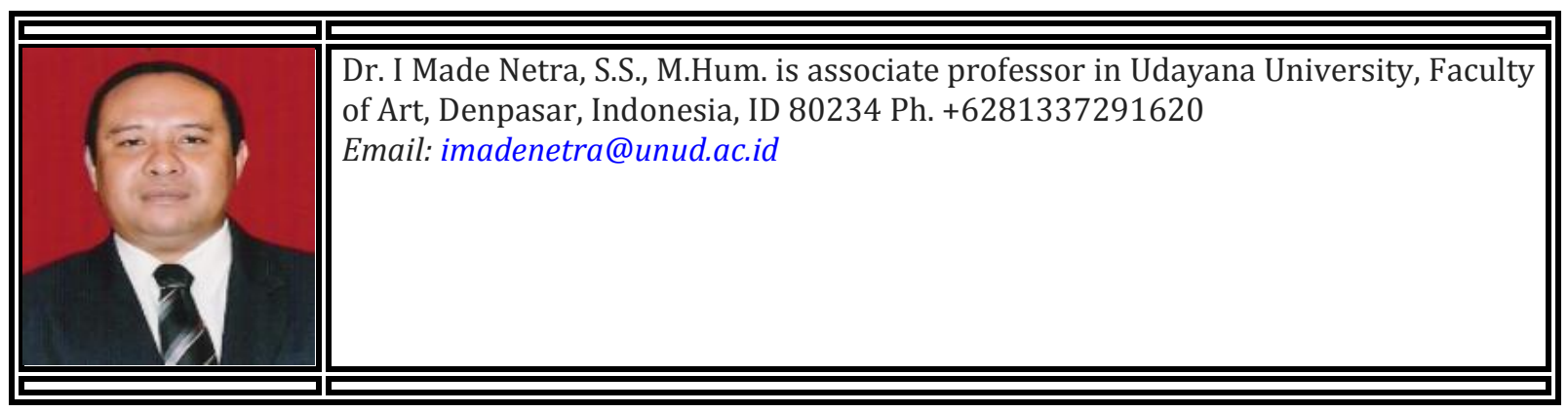

